\section{'Clark' Hazelnut}

\author{
Shawn A. Mehlenbacher ${ }^{1}$, Anita N. Azarenko, David C. Smith, and \\ Rebecca McCluskey \\ Department of Horticulture, 4017 Agricultural and Life Sciences Building, \\ Oregon State University, Corvallis, OR 97331
}

\author{
Additional index words. Corylus avellana, filbert, Anisogramma anomala, eastern filbert \\ blight, nut breeding
}

'Clark' is a new hazelnut (Corylus avellana L.) cultivar for the kernel market. It was released by the Oregon Agricultural Experiment Station in Jan. 1999. Compared with 'Barcelona', Oregon's leading cultivar, 'Clark' has a higher yield efficiency, smaller nuts, higher percentage of kernel (the ratio of kernel to nut weight), better suitability for the blanched kernel market, earlier maturity, and greater quantitative resistance to eastern filbert blight caused by Anisogramma anomala (Peck) E. Müller. 'Clark' is the third cultivar to be released by the Oregon State Univ. (OSU) hazelnut breeding program.

\section{Origin}

'Clark', tested as OSU 276.142, was selected from a progeny of 231 seedlings resulting from a cross of 'Tombul Ghiaghli' $x$ 'Willamette' made by Maxine M. Thompson in 1982. 'Willamette' was released in 1990 (Mehlenbacher et al., 1991). 'Tombul Ghiaghli' was imported from Greece and was described by Raptopolous and Kantartzis (1961). The original 'Clark' tree first set a crop of nuts, a very light crop, in 1987. The larger crop set in 1988 was harvested and evaluated. The original tree performed well in subsequent years and was propagated by tie-off layerage in 1990. The rooted layers were lined out in a nursery row the following season, and then used to plant two replicated trials in Spring 1992, in which 'Barcelona' and 'Willamette' were included as check cultivars. 'Clark' has been evaluated annually in Corvallis since that time. The name was chosen to honor William Clark of the Lewis and Clark Expedition, whose Corps of Discovery spent Winter 1805-06 near Astoria, Ore.

\section{Description}

Trees of 'Clark' are $\approx 70 \%$ of the size of 'Barcelona' trees. They have a globose shape and should be easy to manage in a commercial orchard, although some pruning will be

\footnotetext{
Received for publication 13 Sept. 2000. Accepted for publication 20 Dec. 2000. Oregon Agricultural Experiment Station Technical Paper no. 11711. The cost of publishing this paper was defrayed in part by the payment of page charges. Under postal regulations, this paper therefore must be hereby marked advertisement solely to indicate this fact.

${ }^{1}$ To whom requests for reprints should be addressed. E-mail address: mehlenbs@bcc.orst.edu
} of the pellicle is removed. Thus, blanching of other hazelnut cultivars in two trials planted in 1992. Fall (second trial) 1999, respectively.

${ }^{\mathrm{y}}$ Yield efficiency $=$ Total yield/TCA.

${ }^{\mathrm{x}}$ Mean separation by Waller-Duncan $\mathrm{k}$ ratio $t$ test, $\mathrm{k}$ ratio $=100$. scores for 'Clark' are considerably better than for 'Barcelona' and slightly better than for 'Willamette'. Kernel flavor and texture have been rated as good by several researchers and growers. Nuts of 'Clark' are smaller than those of 'Barcelona' (an average of $2.5 \mathrm{~g}$ for 'Clark' vs. $3.7 \mathrm{~g}$ for 'Barcelona' in the first trial). Because of their small size, the nuts are not suited to the in-shell market. Percentage of kernel averaged $51 \%$ for the original seedling tree and in the 1990 trial, compared with $43 \%$ to $44 \%$ for 'Barcelona'. These figures are based on well-filled nuts. Commercial handlers who find that field-run 'Barcelona' nuts average $40 \%$ kernel can expect 'Clark' to average $\approx 47 \%$. 'Clark' kernels are smaller than those of 'Barcelona' but larger than those of 'Casina'. The diameter of 'Clark' kernels is slightly larger than the $13 \mathrm{~mm}$ considered ideal by European buyers.

'Clark' produces fewer blank nuts than does 'Barcelona' (6\% vs. $11.4 \%$ ) but slightly more moldy kernels (Table 2). Many of the moldy kernels are marketable, as the mold is removed with the pellicle during blanching. The total frequency of defects is considerably lower for 'Clark' than for 'Barcelona' and other important cultivars. When crop load is heavy, the kernels do not completely fill the shells. Nevertheless, most of these kernels are sufficiently plump to be marketable. There is some tendency to bear heavy crops in alternate years. Growers who prune trees in the "on years" will obtain more consistent yields as well as better kernel quality.

'Clark' has incompatibility alleles $\mathrm{S}_{3}$ and $\mathrm{S}_{8}$, both of which are expressed in the stigmas and the pollen. 'Clark' sets many catkins that start to shed pollen in early-midseason, later than 'Barcelona' and 'Ennis', earlier than 'Casina', and at about the same time as 'Willamette'. Female inflorescences are receptive very late, even later than those of 'Ennis' in most years. Thus, late-shedding pollinizers are needed. 'Hall's Giant' is recommended for the early-emerging 'Clark' females, while the very late-shedding pollinizer selections OSU 669.073 and OSU

Table 1. Nut yield, trunk cross-sectional area, and yield efficiency of 'Clark' in comparison with those

\begin{tabular}{|c|c|c|c|c|c|c|c|c|c|c|}
\hline \multirow[b]{2}{*}{ Cultivar } & \multirow{2}{*}{$\begin{array}{l}\text { No. } \\
\text { trees }\end{array}$} & \multicolumn{7}{|c|}{ Yield per tree $(\mathrm{kg})$} & \multirow{2}{*}{$\begin{array}{l}\mathrm{TCA}^{\mathrm{z}} \\
\left(\mathrm{cm}^{2}\right)\end{array}$} & \multirow{2}{*}{$\begin{array}{c}\mathrm{YE}^{\mathrm{y}} \\
\left(\mathrm{kg} \cdot \mathrm{cm}^{-2}\right)\end{array}$} \\
\hline & & 1994 & 1995 & 1996 & 1997 & 1998 & 1999 & Total & & \\
\hline \multicolumn{11}{|c|}{ First trial } \\
\hline Willamette & 5 & 0.46 & 4.89 & 4.54 & 8.18 & 3.93 & --- & 22.00 & 78.3 & 0.28 \\
\hline Mortarella & 5 & 0.18 & 3.70 & 3.61 & 5.22 & 4.45 & --- & 17.15 & 62.0 & 0.28 \\
\hline Lewis & 5 & 0.84 & 4.06 & 2.99 & 5.72 & 2.75 & --- & 16.37 & 78.1 & 0.21 \\
\hline Clark & 5 & 0.36 & 2.38 & 2.60 & 5.06 & 3.00 & --- & 13.40 & 64.1 & 0.21 \\
\hline Negret & 5 & 0.10 & 2.68 & 0.82 & 6.12 & 4.31 & --- & 14.03 & 68.5 & 0.21 \\
\hline Barcelona & 5 & 0.40 & 4.22 & 3.20 & 5.13 & 3.41 & --- & 16.35 & 99.5 & 0.17 \\
\hline $\mathrm{LSD}_{0.05}$ & & 0.18 & 0.51 & 0.58 & 1.09 & 0.97 & --- & 0.65 & 9.7 & 0.02 \\
\hline \multicolumn{11}{|c|}{ Second trial } \\
\hline Willamette & 8 & 0.33 & 4.08 & 2.66 & 9.25 & 4.24 & 10.50 & 31.07 & 108.8 & 0.29 \\
\hline Clark & 8 & 0.53 & 2.12 & 2.13 & 7.29 & 3.02 & 8.83 & 23.92 & 83.5 & 0.29 \\
\hline Barcelona & 8 & 0.45 & 3.76 & 2.40 & 6.90 & 3.29 & 7.51 & 24.31 & 124.2 & 0.20 \\
\hline Casina & 8 & 0.20 & 2.90 & 1.71 & 6.61 & 3.72 & 5.97 & 21.11 & 127.2 & 0.17 \\
\hline $\operatorname{MSD}_{0.05}{ }^{\mathrm{x}}$ & & 0.16 & 0.41 & 0.42 & 0.73 & 0.48 & 0.80 & 1.97 & 10.6 & 0.02 \\
\hline
\end{tabular}

${ }^{\mathrm{z}}$ Trunk cross-sectional area calculated from trunk diameters measured in early Spring (first trial) and late 


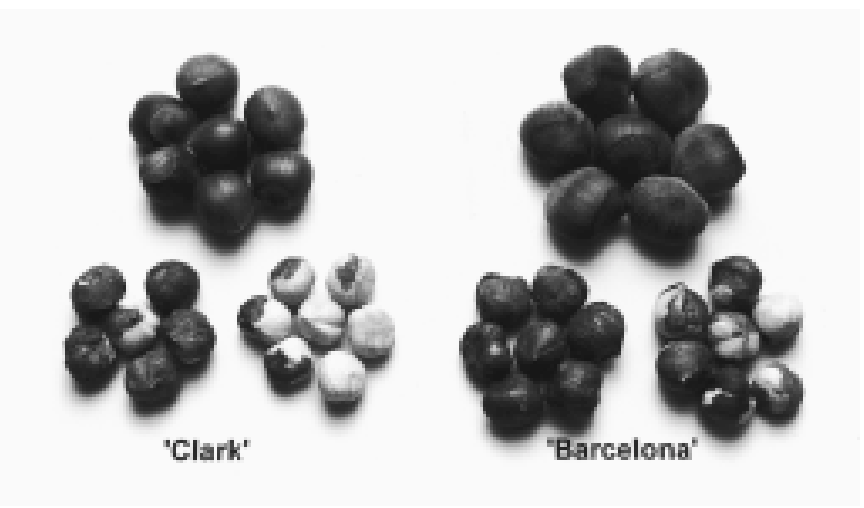

Fig. 1. Nuts and kernels of 'Clark' and of 'Barcelona' hazelnut.

Table 2. Frequency of good nuts, and of nut and kernel defects in 'Clark' and standard hazelnut cultivars in first trial planted in 1992.

\begin{tabular}{lcccccccc}
\hline & \multicolumn{7}{c}{ Avg frequency, 1994-98 } \\
\cline { 2 - 9 } Cultivar & Good & Blanks & $\begin{array}{c}\text { Brown } \\
\text { stain }\end{array}$ & $\begin{array}{c}\text { Poor } \\
\text { fill }\end{array}$ & $\begin{array}{c}\text { Shriveled } \\
\text { kernels }\end{array}$ & $\begin{array}{c}\text { Moldy } \\
\text { kernels }\end{array}$ & $\begin{array}{c}\text { Black } \\
\text { tips }\end{array}$ & $\begin{array}{c}\text { Twin } \\
\text { kernels }\end{array}$ \\
\hline Barcelona & 61 & 11.4 & 0.7 & 21.1 & 0.6 & 1.8 & 0.2 & 3.2 \\
Mortarella & 62 & 9.4 & 2.0 & 14.2 & 0.7 & 5.4 & 0.2 & 6.8 \\
Negret & 69 & 16.0 & 0.2 & 13.1 & 0.5 & 0.6 & 0.6 & 0.1 \\
Willamette & 63 & 5.7 & 0.6 & 21.5 & 1.1 & 8.2 & 0.3 & 1.0 \\
Lewis & 72 & 4.9 & 0.2 & 15.4 & 1.9 & 5.6 & 0.6 & 0.4 \\
Clark & 78 & 6.0 & 1.1 & 8.5 & 0.6 & 3.8 & 1.9 & 0.3 \\
\hline
\end{tabular}

${ }^{\mathrm{a}}$ Five replicate trees per cultivar.

Table 3. Results of three exposures of potted hazelnut trees to eastern filbert blight.

\begin{tabular}{|c|c|c|c|c|}
\hline \multirow[b]{2}{*}{ Year } & \multirow[b]{2}{*}{ Cultivar } & \multicolumn{2}{|c|}{ No. of trees } & \multirow{2}{*}{$\begin{array}{c}\text { Canker } \\
\text { length }(\mathrm{cm})^{y}\end{array}$} \\
\hline & & Exposed & Infected & \\
\hline \multirow{8}{*}{$\overline{1993}$} & Daviana & 13 & 13 & 12.32 \\
\hline & Hall's Giant & 23 & 23 & 11.09 \\
\hline & Willamette & 24 & 23 & 9.67 \\
\hline & Barcelona & 26 & 26 & 9.30 \\
\hline & Clark & 10 & 10 & 6.87 \\
\hline & Tombul Ghiaghli & 8 & 7 & 5.79 \\
\hline & Tonda di Giffoni & 11 & 2 & 0.32 \\
\hline & $\operatorname{LSD}_{0.05}$ & & & 2.17 \\
\hline \multirow[t]{8}{*}{1996} & Daviana & 13 & 13 & 14.51 \\
\hline & Barcelona & 13 & 13 & 11.42 \\
\hline & Willamette & 13 & 13 & 11.15 \\
\hline & Hall's Giant & 13 & 13 & 10.84 \\
\hline & Clark & 16 & 16 & 7.64 \\
\hline & Mortarella & 10 & 10 & 6.90 \\
\hline & Tonda di Giffoni & 10 & 7 & 2.21 \\
\hline & $\mathrm{LSD}_{0.05}$ & & & 2.78 \\
\hline \multirow[t]{7}{*}{1997} & Ennis & 9 & 9 & 10.52 \\
\hline & Hall's Giant & 13 & 13 & 8.92 \\
\hline & Barcelona & 12 & 12 & 7.06 \\
\hline & Mortarella & 10 & 10 & 5.63 \\
\hline & Clark & 13 & 13 & 5.44 \\
\hline & Tonda di Giffoni & 12 & 5 & 1.41 \\
\hline & $\mathrm{LSD}_{0.05}$ & & & 1.53 \\
\hline
\end{tabular}

${ }^{2}$ Trees were exposed in Spring 1993, 1996, and 1997, respectively, and cankers measured after leaf fall 20-22 months later.

${ }^{y}$ Canker lengths were measured in $\mathrm{cm}$ and then summed for each tree. A square root transformation was used to remove the association between mean and variance. The means of the square-root transformed data are shown.
670.095 are recommended to overlap full receptivity of 'Clark' females. Pollen of 'Daviana', 'Butler', 'Gasaway', 'Jemtegaard \#5', 'Lansing \#1', 'Lewis', 'Willamette', VR 20-11, VR 11-27, and VR 23-18 all express $\mathrm{S}_{3}$ and are thus incompatible on 'Clark'. Leaf budbreak of 'Clark' occurs at about the same time as that of 'Willamette', later than 'Barcelona', but earlier than 'Ennis' and 'Casina'.

The susceptibility of hazelnut cultivars to eastern filbert blight is quantified by measuring cankers 20-22 months after exposure of potted trees under structures topped with diseased branches. The three such tests conducted have shown 'Clark' to have a high level of quantitative resistance (Table 3). Although not immune to eastern filbert blight, 'Clark' has a level of resistance that should allow cultivation where the fungus is present, such as in the northern half of the Willamette Valley, if recommended chemical and cultural control practices are followed. Susceptibility to bacterial blight, caused by Xanthomonas campestris pv. corylina, has not been determined, although no trees have been lost to this disease in our trial plots. 'Clark' is moderately susceptible to big bud mite (primarily Phytoptus avellanae Nal.), and ratings are comparable to those of 'Casina'. The use of chemicals should not be necessary to control this pest in most orchards.

Layers of 'Clark' are smaller in height and caliper than those of 'Barcelona', reflecting the lower vigor of the mature trees. The layers root easily and abundantly.

\section{Availability}

'Clark' was released as a public cultivar, and it may be propagated without restriction. Trees are currently available from several nurseries. A list of these nurseries and limited quantities of scion wood are available from S.A.M.

\section{Literature Cited}

Mehlenbacher, S.A., A.N. Miller, M.M. Thompson, H.B. Lagerstedt, and D.C. Smith. 1991. 'Willamette' hazelnut. HortScience 26:13411342.

Raptopolous, T.D. and N.A. Kantartzis. 1961. The most important hazelnut cultivars grown in Greece (in Greek). Yrbk. Sch. Agr. For. Aristotelian Univ., Thessalonika 1961:53-78. 